GRASAS Y ACEITES 68 (1)

January-March 2017, e176

ISSN-L: 0017-3495

doi: http://dx.doi.org/10.3989/gya.0806162

\title{
Influence of de-hulled rapeseed roasting on the physicochemical composition and oxidative state of oil
}

\author{
A. Rękas ${ }^{\mathrm{a},}$, A. Siger ${ }^{\mathrm{b}}$, M. Wroniak ${ }^{\mathrm{a}}$, I. Ścibisz ${ }^{\mathrm{a}}$, D. Derewiaka ${ }^{\mathrm{c}}$ and A. Anders ${ }^{\mathrm{d}}$ \\ ${ }^{a}$ Faculty of Food Sciences, Department of Food Technology, Warsaw \\ University of Life Sciences, Nowoursynowska St. 159c, 02-787 Warsaw, Poland \\ ${ }^{b}$ Faculty of Food Sciences and Nutrition, Department of Food Biochemistry and Analysis, \\ Poznań University of Life Sciences, Wojska Polskiego St. 28, 60-637 Poznań, Poland \\ ${ }^{c}$ Faculty of Food Sciences, Department of Biotechnology, Microbiology and Food Evaluation, \\ Warsaw University of Life Sciences, Nowoursynowska St. 159c, 02-787 Warsaw, Poland \\ ${ }^{\mathrm{d}}$ Faculty of Technical Sciences, Department of Machines and Research Methodology, \\ University of Warmia and Mazury in Olsztyn, M. Oczapowskiego St. 11, 10-736 Olsztyn, Poland \\ ${ }^{\square}$ Corresponding author: agnieszka_rekas@sggw.pl
}

Submitted: 01 August 2016; Accepted: 21 November 2016

SUMMARY: The effect of roasting time on the contents of bioactive compounds (tocopherols, phytosterols, phenolic compounds), antioxidant capacity and physicochemical properties of rapeseed oil pressed from dehulled seeds was investigated. The de-hulled seeds were roasted at a temperature of $165^{\circ} \mathrm{C}$ for $20,40,60,80$, and $100 \mathrm{~min}$. The results of this study show that a roasting pre-treatment led to a gradual increase in canolol content (from 1.34 to $117.33 \mathrm{mg} / 100 \mathrm{~g}$ ), total phytosterols (from 573.51 to $609.86 \mathrm{mg} / 100 \mathrm{~g}$ ) and total carotenoids $(0.82$ to $2.41 \mathrm{mg} / 100 \mathrm{~g})$, while only slight changes in the contents of tocopherols were noted. With the increase in roasting time a gradual increase in oxidative stability (from 4.27 to $6.85 \mathrm{~h}$ ), and antioxidant capacity, seen mainly in the hydrophilic fraction of oil (from 0.32 to $2.30 \mathrm{mmol}$ TEAC/l) was found. Although roasting resulted in the formation of primary and secondary oxidation products, the quality parameters of oils were within Codex Alimentarius limits.

KEYWORDS: Bioactive compounds; De-hulling; Oxidative stability; Radical scavenging activity; Rapeseed oil; Roasting

RESUMEN: Influencia del tostado de colza descascarillada sobre la composición fisicoquímica y el estado oxidativo del aceite. Se estudió el efecto del tiempo de tostado sobre el contenido de compuestos bioactivos (tocoferoles, fitoesteroles, compuestos fenólicos), capacidad antioxidante y propiedades fisicoquímicas del aceite de prensado de semillas descascarilladas de colza. Las semillas descascarilladas se tostaron a una temperatura de 165 ${ }^{\circ} \mathrm{C}$ durante 20, 40, 60, 80 y $100 \mathrm{~min}$. Los resultados de este estudio muestran que el pretratamiento con tostado condujo a un aumento gradual del contenido de canolol (de 1,34 a 117,33 mg/100 g), fitosteroles totales (de 573,51 a $609,86 \mathrm{mg} / 100 \mathrm{~g}$ ) y carotenoides totales $(0,82$ a $2,41 \mathrm{mg} / 100 \mathrm{~g}$ ). Sólo se observaron ligeros cambios en el contenido de tocoferoles. Con el incremento del tiempo de tostado se observó un aumento gradual de la estabilidad oxidativa (de 4,27 a 6,85 h) y se encontró capacidad antioxidante, observada principalmente en la fracción hidrofílica de aceite (de 0,32 a 2,30 mmol TEAC/l). Aunque, el tostado produjo formación de productos de oxidación primaria y secundaria, los parámetros de calidad de los aceites estaban dentro de los límites del Codex Alimentarius.

PALABRAS CLAVE: Aceite de colza; Actividad de barrido radical; Compuestos bioactivos; Descascarillado; Estabilidad oxidativa; Tostado

ORCID ID: Rękas A http://orcid.org/0000-0001-5979-8430, Siger A http://orcid.org/0000-0002-3681-153X, Wroniak M http://orcid.org/0000-0002-8527-7185, Ścibisz I http://orcid.org/0000-0003-1291-8962, Derewiaka D http://orcid. org/0000-0002-2817-6513, Anders A http://orcid.org/0000-0001-6950-4141

Citation/Cómo citar este artículo: Rękas A, Siger A, Wroniak M, Ścibisz I, Derewiaka D, Anders A. 2017. Influence of de-hulled rapeseed roasting on the physicochemical composition and oxidative state of oil. Grasas Aceites $\mathbf{6 8}, \mathrm{e} 176$. http://dx.doi.org/10.3989/gya.0806162

Copyright: (C) 2017 CSIC. This is an open-access article distributed under the terms of the Creative Commons Attribution (CC-by) Spain 3.0 License. 


\section{INTRODUCTION}

The EU is the world's largest producer of rapeseed and its products. The leading countries in rapeseed production in the EU are Germany and France, followed by the U.K., Poland, and the Czech Republic (FAOSTAT, 2015). Besides the food use of rapeseed, its meal is used in the livestock sector as the EU is a leading producer and exporter of meat and dairy products. Recently, the main driver for the demand of oil is the biodiesel industry, as rapeseed oil has become the primary feedstock for biodiesel in Europe.

The seeds of rape consist of three basic components: the embryo, the endosperm and the seed coat (hull). Endosperm degenerates during seed maturation and the seed coat enwraps the embryo tightly. The embryo contains two pieces of cotyledons (which serve as food reserve structures), radicle and hypocotyl (Hu et al., 2013). The oil in this oilseed is distributed in spherosomes throughout the germ cell. Rapeseeds are composed of $38-50 \%$ lipid, $20-32 \%$ protein, and $10-15 \%$ crude fiber. These major rapeseed constituents are not evenly distributed throughout the rapeseed. The respective oil contents for hulls and kernels range from 10.6 to $16.4 \%$ (dry basis) and from 47.1 to $59.6 \%$. The protein content of the hulls ranges from $17-18 \%$ (de-fatted dry basis), while the protein content in defatted kernels ranges from $46 \%$ up to $79 \%$. Crude fiber contents range from 27.0 to $44.1 \%$ (dry basis) in de-fatted hulls and 3.0\% to $12 \%$ in de-oiled kernels (Carré et al., 2016).

Today's consumers have a different opinion concerning the cold-pressed rapeseed oil flavor. For some, it is valued for its unique fresh and mild taste resembling asparagus, cabbage or fresh green vegetables. Others find it unpleasant due to its pungent odor which is a consequence of the breakdown products of glucosinolate supervention (Brühl and Matthäus, 2008). An alternative may constitute rapeseed oil extraction from the hulled rapeseeds. Rapeseed dehulling prior to pressing allows for improving the sensory characteristic of the oil (removal of hull pigments, reduction in phenolic acid tannin content responsible for the bitter and astringent after-taste and the dark color of crude oil) as well as the quality of the meal (increase in protein content, reduction in fiber content) (Carré et al., 2016). Studies conducted by Yang et al. (2011) investigated the effect of rapeseed hulling prior to cold-pressing on the composition and oxidative stability of oil. Guderjan et al. (2007) compared the application of pulsed electric fields on oil yield and phytochemicals of rapeseed oil pressed from hulled and non-hulled seeds. The results obtained in this study showed favorable effect of seed de-hulling on the extractability of bioactive compounds during pressing. Zhou et al. (2013), who studied the effect of rapeseed pre-treatment with de-hulling and microwaving on the flavor characteristics of cold-pressed rapeseed, found that a dehulling pre-treatment could improve the flavor of the oil. Thermal rapeseed pre-processing techniques, such as roasting (Shrestha and De Melnauer, 2014; Rękas et al., 2015; Siger et al., 2015), microwave pre-treatment (Spielmeyer et al., 2009; AzadmardDamirchi et al., 2010; Yang et al., 2013; Yang et al., 2014) showed the favorable effect of high temperatures on oil yield, the extractability of functional oil ingredients (tocopherols, phytosterols, carotenoids) and the formation of new compounds (canolol). The aim of the present study was to investigate the impact of rapeseed hulling in conjunction with different roasting times on the phytochemical contents, antioxidant capacity and oxidative stability of the oil.

\section{MATERIALS AND METHODS}

\subsection{Experimental material}

Seeds of the winter-type rapeseed, Bojan, were provided by the Plant Breeding Strzelce Ltd. Co. - IHAR Group, Poland. The seeds were harvested at optimum maturity, and did not contain any impurities or broken seeds. They were stored in paper bags under atmospheric conditions at $19 \pm 1{ }^{\circ} \mathrm{C}$.

\subsection{Reagents}

Analytical standards $\alpha-, \beta$-, $\gamma$-, and $\delta$-tocopherols (>95\%), HPLC-grade $n$-hexane, methanol, formic acid, and 1,4-dioxane were purchased from CalbiochemMerck Biosciences (Darmstadt, Germany). Phenolic acid standards, Sylon BTZ, 5a-cholestane (> 97\%) 2,2-diphenyl-1-picrylhyd razyl radical (DPPH), and ( \pm )-6-hydroxy-2,5,7,8-tetramethylchroman-2carboxylic acid (Trolox) were purchased from SigmaAldrich (St. Louis, MO, USA).

\subsection{Mechanical de-hulling}

Mechanical de-hulling of rapeseeds was performed using a shearing disc sheller equipped with cylindrical blades, developed by Anders (2003). The height of the slot between the hulling disk and the top cover of the working space was $3 \mathrm{~mm}$. The hulling disk had a diameter of $140 \mathrm{~mm}$, and was equipped with blades inclined at 45 degrees to the flat surface of the disk. De-hulled rapeseeds were subjected to pneumatic separation on a laboratory separator Petkus K-293 (PETKUS Technolologie GmbH, Germany).

\subsection{Roasting conditions}

De-hulled rapeseeds were equilibrated at refrigerated temperature $\left(4 \pm 2{ }^{\circ} \mathrm{C}\right)$ in closed containers for $72 \mathrm{~h}$ to reach a moisture content of $7.5 \%$ by spraying 
the seeds with a specific amount of water. For each sample, $500 \mathrm{~g}$ of de-hulled rapeseeds were thinly and evenly spread out on the bottom of a glass beaker, tightly covered with aluminium foil, and heated for $20,40,60,80$, and $100 \mathrm{~min}$ inside an oven with forced ventilation (SUP-100, WAMED, 2600 W) maintained at a temperature of $165^{\circ} \mathrm{C}$. A de-hulled rapeseed sample without thermal treatment was used as a control sample. Following each heating run, the seeds were allowed to cool to ambient temperature and were thoroughly mixed to obtain a homogenous sampling. Then, the seeds were re-moisturized to reach required moisture level of $8.5 \%$ prior to pressing. Each experiment was performed in triplicate for all variants of roasting.

\subsection{Oil extraction by cold-pressing}

The oil was pressed with the use of screw press (Farmet, Czech Republic) at room temperature $\left(20 \pm 2{ }^{\circ} \mathrm{C}\right)$. During the pressing, the temperature was kept below $40{ }^{\circ} \mathrm{C}$. After pressing the oils were collected, subjected to natural sedimentation ( 3 days) under refrigeration conditions $\left(4 \pm 2{ }^{\circ} \mathrm{C}\right)$ and decanted.

\subsection{Analysis of biochemical composition of oils}

To determine tocochromanols $(\alpha-, \beta-, \gamma-$, and $\delta$-tocopherol and PC-8), $200 \mathrm{mg}$ of oil were dissolved in $10 \mathrm{ml}$ of $n$-hexane and transferred to vials for further analysis. Separation was performed using a Waters HPLC system (Waters, Milford, MA, USA) coupled with a FLD detector (Waters 474), a PDA detector (Waters 2998), and a LiChrosorb Si 60 column $(250 \times 4.6 \mathrm{~mm}, 5 \mu \mathrm{m}$, Merck Millipore, Darmstadt, Germany). The mobile phase was a mixture of $n$-hexane with 1,4-dioxane $(96: 4 \mathrm{v} / \mathrm{v})$ at a flow rate $1.0 \mathrm{~mL} \cdot \mathrm{min}^{-1}$. Quantification of tocochromanols was conducted using data from the FLD with excitation/emission wavelengths of 295/330 nm, respectively. The plastochromanol-8 content was assayed and calculated according to the method described by Siger et al. (2014).

Phytosterols were determined following the procedures described by the AOCS Official Method Ch 6-91 (1997). In brief, a 50-mg oil sample was saponified with $1 \mathrm{M}$ methanolic $\mathrm{KOH}$ at room temperature for $18 \mathrm{~h}$. Then, $700 \mu \mathrm{L}$ of unsaponified fraction were transferred into a $1.5 \mathrm{~mL}$ vial and the solvent was evaporated to dryness under nitrogen. Dry residues were dissolved in $100 \mu \mathrm{L}$ pyridine and silylated with $400 \mu \mathrm{L}$ of Sylon BTZ. Derivatives of the sterols were separated on a gas chromatograph (Shimadzu, Japan) equipped with a FID detector, using qa DB-5MS capillary column $(30 \mathrm{~m} \times 0,25 \mathrm{~mm}$ $\times 0,25 \mu \mathrm{m}$; Phenomenex Torrance, CA, USA). $1 \mu \mathrm{L}$ of the sample was injected in splitless mode (setup: hydrogen carrier gas at $1.5 \mathrm{ml} \mathrm{min}^{-1}$ flow rate, the detector temperature was set at $300^{\circ} \mathrm{C}$ ). The column temperature: $50^{\circ} \mathrm{C}$ held for $2 \mathrm{~min}$, ramped to $230^{\circ} \mathrm{C}$ at $15{ }^{\circ} \mathrm{C} \cdot \mathrm{min}^{-1}$, ramped to $310^{\circ} \mathrm{C}$ at $3^{\circ} \mathrm{C} \cdot \mathrm{min}^{-1}$, held for $10 \mathrm{~min}$. All sterols were quantified using $5 \alpha$-cholestanol as internal standard. The identification was based on a GC-MSn laboratory sterol spectra library, as well as the online NIST mass spectra library.

The analysis was carried out using the Shimadzu HPLC system (Shimadzu, Japan), equipped with a Luna C18 reversed-phase column $(4.6 \times 250 \mathrm{~mm}$; $5 \mu \mathrm{m}$, Phenomenex, Torrance, CA, USA), and a DAD detector. The solid-phase extraction (SPE) of phenolic compounds was carried out following the method presented by Siger et al. (2015). Gradient elution was used, combining solvent A (formic acid: $\mathrm{H}_{2} \mathrm{O} 900: 100 \mathrm{v} / \mathrm{v}$ ) and solvent $\mathrm{B}$ (methanol) as follows: $10 \% \mathrm{~B}(0-1 \mathrm{~min}), 20 \% \mathrm{~B}$ (10-22 $\mathrm{min})$, $50 \%$ B (22-45 min), 70\% B (45-55 min), 90\% B (55-60 min), 10\% B (60-65 min), 10\% B (65-75 $\mathrm{min})$. The flow rate was $1.0 \mathrm{~mL} \cdot \mathrm{min}^{-1}$. The injection volume was $20 \mu \mathrm{L}$, while the column temperature was maintained at $25^{\circ} \mathrm{C}$. The signal was monitored at 200-600 nm using a DAD detector (SPD-M20A, Shimadzu, Japan). A quantitative determination of phenolic compounds was carried out by comparing the retention times and diode array spectral characteristics with the appropriate standards. HPLC/ ESI/MS ${ }^{\mathrm{n}}$ analyses were performed to qualitatively identify phenolic compounds that differed in their retention times from the standards.

The isolation and identification of canolol was performed using a Waters HPLC system (Waters, Milford, MA, USA) with a FLD detector (Waters 474), a PDA detector (Waters 2998), equipped with a Nova-Pack silica semi-preparative column $(19 \times 300 \mathrm{~mm}, 6 \mu \mathrm{m}$, Waters, USA), following the method presented by Siger et al. (2015). The oil ( $1 \mathrm{~g})$ was dissolved in $n$-hexane, made up to 10 $\mathrm{ml}$, and $200 \mu \mathrm{l}$ were applied onto the column. The mobile phase consisted of $n$-hexane and 1,4-dioxane $(96: 4 \mathrm{v} / \mathrm{v})$ and the flow rate was $3 \mathrm{ml} \mathrm{min}^{-1}$. The canolol containing fraction $(\mathrm{RT}=43,106 \mathrm{~min}$ ) was collected under nitrogen in a sealed, round-bottom flask. This procedure was repeated several times to obtain a high concentration of canolol. The solvent was evaporated under nitrogen and the isolated canolol was dissolved in $n$-hexane in a $10 \mathrm{ml}$ volumetric flask. The concentration of canolol was evaluated spectrophotometrically according to its specific absorption coefficient: $29,000 \lambda=218 \mathrm{~nm}$ ) and 13,000 ( $\lambda=269 \mathrm{~nm}$ ) (Aachary and ThiyamHolländer, 2013). Peak identity and homogeneity was verified using HPLC-MS ${ }^{\mathrm{n}}$.

The total phenolic compound content was determined by the Folin-Ciocalteau method following procedure presented by Koski et al. (2002). In brief, an aliquot $(0.2 \mathrm{~mL})$ of methanolic extract was mixed with $0.5 \mathrm{ml}$ of a Folin-Ciocalteau reagent and 
sodium carbonate solution $(1 \mathrm{~mL})$. After $60 \mathrm{~min}$ of reaction in the absence of light, the absorbance was measured at $725 \mathrm{~nm}$. Sinapic acid was used as a standard, and the results were expressed in $\mathrm{mg}$ of sinapic acid equivalent $/ 100 \mathrm{~g}$ of sample.

Total carotenoid pigments, expressed as $\beta$-carotene, were assayed spectrophotometrically for oil samples diluted in cyclohexane at $445 \mathrm{~nm}$ (BSI, 1977). The total chlorophyll pigments, expressed as pheophytin $a$, were determined according to the AOCS Method (1997) by measuring the absorbance of the oil against the air at 630,670, and $710 \mathrm{~nm}$.

\subsection{Determination of color development of oils}

The measurement of the oil color was conducted with a CM-3600d colorimeter (Konica Minolta, Japan), in a CIE L*a*b* system, using illuminant D65 and $10^{\circ}$ observer angle. The values of the $\mathrm{L}^{*}, \mathrm{a}^{*}$ and $b^{*}$ parameters allowed for the calculation of the absolute difference of the samples' color $(\Delta \mathrm{E})$ after roasting pre-treatment compared to the control:

$$
\Delta \mathrm{E}=\left[\left(\mathrm{L}_{0}-\mathrm{L}\right)^{2}+\left(\mathrm{a}_{0} *-\mathrm{a} *\right)^{2}+\left(\mathrm{b}_{0} *-\mathrm{b}^{*}\right)^{2}\right]^{1 / 2} .
$$

The non-enzymatic browning index was assayed spectrophotometrically for oil samples diluted in chloroform at $420 \mathrm{~nm}$ (Yoshida et al., 1999).

\subsection{Radical scavenging of oils (RSC)}

To evaluate the antioxidant activity of the oils, a spectrophotometric analysis was performed using 2,2-diphenyl-1-picrylhydrazyl (DPPH), following the method described by Tuberoso et al. (2007). The antioxidant activity of the oil (TF) and both lipophilic (LF) and hydrophilic (HF) fractions was determined. To separate the HF and LF, $500 \mu \mathrm{L}$ of oil was mixed with $500 \mu \mathrm{L}$ of methanol, and then they were shaken in a vibration mixer for $10 \mathrm{~s}$, shaken in a rotary shaker for $30 \mathrm{~min}$, and centrifuged at $700 \mathrm{~g}$ for $10 \mathrm{~min}$ to allow the fractions to separate. HF was tested using $20 \mu \mathrm{l}$ of extract added to $3 \mathrm{ml}$ of methanolic DPPH $(0.04 \mathrm{mM})$, while the LF and TF assay was performed using DPPH dissolved in ethyl acetate. Spectrophotometric readings were carried out after a $1 \mathrm{~h}$ period of incubation with a Spectronic Helios $\beta$ UV-Vis spectrophotometer at $517 \mathrm{~nm}$ using a $10-\mathrm{mm}$ quartz cuvette. Results were expressed as a Trolox equivalent antioxidant capacity (TEAC, mmol/l), using a Trolox calibration curve in the range of $0.02-4.00 \mathrm{mM}$.

\subsection{Analysis of oxidative stability of oils}

The peroxide value (PV), $p$-anisidine value ( $p$-AnV), and specific UV extinctions ( $K_{232}$ and $K_{268}$ values) were determined in accordance with the ISO standard methods (ISO, 2005, 2008, 2011, respectively).
The oxidative stability of the oil samples was evaluated by the Metrohm Rancimat apparatus model 743 (Herisau, Switzerland). Briefly, oil samples were weighed $(2.5 \mathrm{~g})$ into the reaction vessel and heated to $120{ }^{\circ} \mathrm{C}$ under the air flow of $20 \mathrm{~L} / \mathrm{h}$. The induction period (IP) was expressed in hours (h).

\subsection{Statistical analysis}

Data are expressed as Mean \pm SD. To examine the effect of the microwave pre-treatment of rapeseeds on the crude oil variables studied, one-way ANOVA was used when the variables fulfilled parametric conditions, and the Kruskal-Wallis test when they were non-parametric. Correlations between variables studied were determined using Pearsons's correlation coefficient $(r)$. Significance was established at a probability of $p<0.05$, using the Statistica 12.0 software (StatSoft, Inc., Tulsa, OK).

\section{RESULTS}

\subsection{Effect of de-hulled rapeseed roasting on the content of bioactive compounds}

As can be seen in Table 1, $\alpha$ - and $\gamma$-tocopherol were the predominant tocopherol homologues in the analyzed oil samples, and their contents in the control oil sample were 25.13 and $38.66 \mathrm{mg} / 100 \mathrm{~g}$, while the other tocopherol homologues, such as $\delta$ - and $\beta$-tocopherol, were present in much smaller quantities $(0.61$ and $0.08 \mathrm{mg} / 100 \mathrm{~g}$, respectively). $\alpha$-Tocopherol was thermal-sensitive, the content of which decreased to 21.02 and $21.21 .74 \mathrm{mg} / 100 \mathrm{~g}$ with 60 and $80 \mathrm{~min}$ of roasting, respectively. However, the amount of $\alpha$-T after $100 \mathrm{~min}$ of roasting was $25.54 \mathrm{mg} / 100 \mathrm{~g}$, which was nearly the same as the amount of $\alpha-T$ in the control oil sample. On the other hand, a gradual increase in $\gamma$-T content was noted, as a result of a longer seed roasting time, reaching its maximum concentration of $46.71 \mathrm{mg} / 100 \mathrm{~g}$ after $100 \mathrm{~min}$ of roasting. The roasting pre-treatment of rapeseed prior to pressing significantly $(p<0.05)$ increased the content of plastochromanol-8 (PC-8) in the analyzed oil samples (Table 1). The seed roasting for 100 min resulted in an increase of the PC- 8 content of $73.6 \%$, compared to the control oil sample (increased from 2.42 to $4.20 \mathrm{mg} / 100 \mathrm{~g}$ ).

The control rapeseed oil contained a total of $573.51 \mathrm{mg} / 100 \mathrm{~g}$ phytosterols, among which the dominant phytosterols were $\beta$-sitosterol, campesterol, and brassicasterol, accounting for $52 \%$, $31 \%$, and $14 \%$ of the total phytosterol contents, respectively (Table 1). The roasting pre-treatment of rapeseeds exerts a significant effect on the content of phytosterols in the oil. The respective increase in the concentration of brassicasterol, campesterol, and $\beta$-sitosterol following $100 \mathrm{~min}$ of 
TABLE 1. Tocochromanol, phytosterol and phenolic compound contents ( $\mathrm{mg} / 100 \mathrm{~g})$ in rapeseed oil samples produced from de-hulled roasted seeds

\begin{tabular}{|c|c|c|c|c|c|c|}
\hline Roasting time (min) & $\mathbf{0}$ & 20 & 40 & 60 & 80 & 100 \\
\hline \multicolumn{7}{|l|}{ Tocochromanols (mg/100 g) } \\
\hline$\alpha$-Tocopherol & $25.13 \pm 0.15^{\mathrm{a}}$ & $25.29 \pm 0.14^{\mathrm{a}}$ & $25.84 \pm 0.15^{\mathrm{a}}$ & $21.02 \pm 0.27^{\mathrm{b}}$ & $21.74 \pm 0.1^{\mathrm{b}}$ & $25.54 \pm 0.09^{\mathrm{a}}$ \\
\hline$\beta$-Tocopherol & $0.08 \pm 0.02^{\mathrm{a}}$ & $0.09 \pm 0.04^{\mathrm{a}}$ & $0.08 \pm 0.02^{\mathrm{a}}$ & $0.10 \pm 0.02^{\mathrm{a}}$ & $0.09 \pm 0.03^{\mathrm{a}}$ & $0.16 \pm 0.21^{\mathrm{a}}$ \\
\hline$\gamma$-Tocopherol & $38.66 \pm 0.17^{\mathrm{b}}$ & $38.77 \pm 0.07^{\mathrm{b}}$ & $39.35 \pm 0.24^{\mathrm{a}}$ & $40.66 \pm 0.21^{\mathrm{b}}$ & $46.16 \pm 0.09^{c}$ & $46.71 \pm 0.22^{\mathrm{c}}$ \\
\hline$\delta$-Tocopherol & $0.61 \pm 0.04^{\mathrm{a}}$ & $0.72 \pm 0.03^{\mathrm{b}}$ & $0.71 \pm 0.05^{\mathrm{b}}$ & $0.72 \pm 0.04^{\mathrm{b}}$ & $0.67 \pm 0.02^{\mathrm{a}}$ & $0.63 \pm 0.01^{\mathrm{a}}$ \\
\hline Total tocopherols & $64.88 \pm 0.20^{\mathrm{b}}$ & $64.87 \pm 0.09^{b}$ & $65.97 \pm 0.12^{\mathrm{c}}$ & $62.50 \pm 0.43^{\mathrm{a}}$ & $68.66 \pm 0.07^{\mathrm{d}}$ & $73.04 \pm 0.51^{\mathrm{e}}$ \\
\hline PC-8 & $2.42 \pm 0.05^{\mathrm{a}}$ & $2.46 \pm 0.08^{\mathrm{a}}$ & $3.55 \pm 0.09^{\mathrm{b}}$ & $3.86 \pm 0.09^{\mathrm{b}}$ & $4.42 \pm 0.15^{\mathrm{c}}$ & $4.20 \pm 0.15^{\mathrm{c}}$ \\
\hline \multicolumn{7}{|l|}{ Phytosterols (mg/100 g) } \\
\hline Cholesterol & $1.77 \pm 0.01^{\mathrm{a}}$ & $1.76 \pm 0.07^{\mathrm{a}}$ & $1.77 \pm 0.02^{\mathrm{a}}$ & $1.75 \pm 0.12^{\mathrm{a}}$ & $1.74 \pm 0.08^{\mathrm{a}}$ & $1.71 \pm 0.02^{\mathrm{a}}$ \\
\hline Brassicasterol & $77.86 \pm 0.11^{\mathrm{a}}$ & $76.02 \pm 0.25^{\mathrm{a}}$ & $81.18 \pm 0.42^{\mathrm{b}}$ & $86.32 \pm 0.37^{\mathrm{c}}$ & $89.35 \pm 0.17^{\mathrm{d}}$ & $93.42 \pm 0.23^{\mathrm{e}}$ \\
\hline Campesterol & $176.08 \pm 5.12^{\mathrm{a}}$ & $175.37 \pm 4.02^{\mathrm{a}}$ & $179.02 \pm 3.41^{\mathrm{b}}$ & $183.93 \pm 4.81^{\mathrm{c}}$ & $188.92 \pm 5.05^{\mathrm{d}}$ & $192.10 \pm 2.21^{\mathrm{e}}$ \\
\hline Stigmasterol & $2.89 \pm 0.02^{\mathrm{b}}$ & $2.82 \pm 2.03^{\mathrm{a}}$ & $2.88 \pm 0.05^{\mathrm{b}}$ & $2.91 \pm 0.08^{\mathrm{b}}$ & $2.92 \pm 0.03^{\mathrm{b}}$ & $2.88 \pm 0.06^{\mathrm{b}}$ \\
\hline$\beta$-Sitosterol & $297.88 \pm 5.02^{\mathrm{b}}$ & $296.36 \pm 3.97^{\mathrm{a}}$ & $299.34 \pm 4.04^{\mathrm{b}}$ & $301.42 \pm 6.03^{\mathrm{c}}$ & $298.37 \pm 3.52^{\mathrm{b}}$ & $303.36 \pm 8.11^{\mathrm{c}}$ \\
\hline$\Delta 5$-Avenasterol & $17.03 \pm 0.03^{\mathrm{a}}$ & $17.08 \pm 0.12^{\mathrm{a}}$ & $18.04 \pm 0.20^{\mathrm{b}}$ & $19.03 \pm 0.02^{\mathrm{c}}$ & $19.96 \pm 0.06^{\mathrm{c}}$ & $16.39 \pm 0.05^{\mathrm{a}}$ \\
\hline Total phytosterols & $573.51 \pm 4.15^{\mathrm{b}}$ & $569.41 \pm 3.39^{\mathrm{a}}$ & $582.23 \pm 4.01^{\mathrm{b}}$ & $595.36 \pm 5.11^{\mathrm{d}}$ & $601.26 \pm 4.07^{\mathrm{e}}$ & $609.86 \pm 7.16^{\mathrm{f}}$ \\
\hline \multicolumn{7}{|l|}{ Phenolic compounds (mg/100 g) } \\
\hline Canolol & $1.34 \pm 0.04^{\mathrm{a}}$ & $2.52 \pm 0.09^{b}$ & $18.74 \pm 0.10^{\mathrm{c}}$ & $69.28 \pm 0.13^{\mathrm{d}}$ & $88.44 \pm 0.19^{\mathrm{e}}$ & $117.33 \pm 0.32^{\mathrm{f}}$ \\
\hline trans-Sinapic acid & $0.20 \pm 0.00^{\mathrm{a}}$ & $0.23 \pm 0.00^{\mathrm{b}}$ & $0.25 \pm 0.00^{\mathrm{b}}$ & $0.33 \pm 0.00^{\mathrm{c}}$ & $0.47 \pm 0.01^{\mathrm{d}}$ & $0.40 \pm 0.00^{\mathrm{d}}$ \\
\hline Sinapic acid methyl ester & $0.00 \pm 0.00^{\mathrm{a}}$ & $0.00 \pm 0.00^{\mathrm{a}}$ & $0.00 \pm 0.00^{\mathrm{a}}$ & $0.02 \pm 0.00^{\mathrm{a}}$ & $0.02 \pm 0.00^{\mathrm{a}}$ & $0.03 \pm 0.00^{\mathrm{a}}$ \\
\hline Ferulic acid & $0.02 \pm 0.00^{\mathrm{a}}$ & $0.02 \pm 0.00^{\mathrm{a}}$ & $0.02 \pm 0.00^{\mathrm{a}}$ & $0.02 \pm 0.00^{\mathrm{a}}$ & $0.04 \pm 0.00^{\mathrm{b}}$ & $0.03 \pm 0.00^{\mathrm{b}}$ \\
\hline Sinapine & $0.03 \pm 0.00^{\mathrm{a}}$ & $0.01 \pm 0.00^{\mathrm{a}}$ & $0.03 \pm 0.00^{\mathrm{a}}$ & $0.09 \pm 0.00^{\mathrm{b}}$ & $0.12 \pm 0.00^{\mathrm{b}}$ & $0.15 \pm 0.00^{\mathrm{b}}$ \\
\hline$p$-Coumaric acid & $0.02 \pm 0.00^{\mathrm{a}}$ & $0.01 \pm 0.00^{\mathrm{a}}$ & $0.01 \pm 0.00^{\mathrm{a}}$ & $0.01 \pm 0.00^{\mathrm{a}}$ & $0.01 \pm 0.00^{\mathrm{a}}$ & $0.02 \pm 0.00^{\mathrm{a}}$ \\
\hline $\begin{array}{l}\text { Total phenolic compounds - } \\
\text { HPLC }\end{array}$ & $1.61 \pm 0.01^{\mathrm{a}}$ & $2.79 \pm 0.05^{\mathrm{b}}$ & $19.05 \pm 0.04^{\mathrm{c}}$ & $69.75 \pm 0.06^{\mathrm{d}}$ & $89.10 \pm 0.03^{\mathrm{e}}$ & $117.96 \pm 0.13^{\mathrm{f}}$ \\
\hline $\begin{array}{l}\text { Total phenolic compounds - } \\
\text { Folin-Ciocalteau }\end{array}$ & $3.62 \pm 0.26^{\mathrm{a}}$ & $4.14 \pm 0.75^{b}$ & $25.64 \pm 1.54^{\mathrm{c}}$ & $81.23 \pm 4.34^{\mathrm{d}}$ & $112.98 \pm 3.15^{\mathrm{e}}$ & $201.17 \pm 8.51^{\mathrm{f}}$ \\
\hline
\end{tabular}

Mean values denoted by the same letter in rows do not constitute statistically significant differences at $p<0.05$.

roasting was $19.9 \%, 9.1 \%$, and $1.8 \%$, compared to the control. The amount of the remaining phytosterols, namely stigmasterol, $\Delta 5$-avenasterol, and cholesterol, remained practically unchanged in all roasting times.

The level of the total phenolic compounds in the control oil measured by the Folin-Ciocalteau method was $3.62 \mathrm{mg} / 100 \mathrm{~g}$, while the total phenolic content calculated from HPLC-DAD was $1.61 \mathrm{mg} / 100 \mathrm{~g}$. Roasting the seeds prior to pressing significantly increased the amount of total polyphenols in the analyzed rapeseed oil (Table 1). The results related to the changes observed in the individual phenolic compounds of the rapeseeds submitted to roasting are displayed in Table 1. The control rapeseed oil contained relatively low amounts of phenolic compounds, represented by canolol, trans-sinapic acid and its methyl ester, sinapine, ferulic acid and $p$-coumaric acid. The dominant phenolic compound was canolol, which accounted for $84 \%$ of the total phenolic content.
Along with increasing seed roasting time, only minor changes in the quantities of polar phenolics in the oil were found, while the amount of canolol increased significantly. The most pronounced changes in the canolol content occurred after rapeseed roasting for $60 \mathrm{~min}$ : the amount of this compound increased to $69.28 \mathrm{mg} / 100 \mathrm{~g}$ (over a 50 -fold increase when compared to the control oil sample, and nearly a 4-fold increase in comparison with the canolol content in the oil pressed from seeds roasted for $40 \mathrm{~min}$ ). Further roasting time prolongation resulted in a rapid canolol formation: after $80 \mathrm{~min}$ of roasting the concentration of canolol was $88.44 \mathrm{mg} / 100 \mathrm{~g}$, while the maximum canolol content of $117.33 \mathrm{mg} / 100 \mathrm{~g}$ was found in oil pressed from seeds roasted for $100 \mathrm{~min}$.

The control oil sample contained 0.82 and $0.24 \mathrm{mg} / 100 \mathrm{~g}$ of total carotenoid and chlorophyll pigments, respectively. Extending the time of the seeds' thermal treatment yielded a significant increase in pigment concentration in the oil 
TABLE 2. CIE L*a*b* values ${ }^{\dagger}$ and color parameters of rapeseed oils produced from de-hulled roasted seeds

\begin{tabular}{lcccccc}
\hline Roasting time (min) & $\mathbf{0}$ & $\mathbf{2 0}$ & $\mathbf{4 0}$ & $\mathbf{6 0}$ & $\mathbf{8 0}$ & $\mathbf{1 0 0}$ \\
\hline $\mathbf{C I E ~ L * a * b *}$ values $^{*} \mathbf{L}^{*}$ & $96.05 \pm 0.03^{\mathrm{b}}$ & $95.12 \pm 0.01^{\mathrm{b}}$ & $95.01 \pm 0.01^{\mathrm{b}}$ & $94.33 \pm 0.02^{\mathrm{a}}$ & $94.02 \pm 0.03^{\mathrm{a}}$ & $93.12 \pm 0.02^{\mathrm{a}}$ \\
$\mathrm{a}^{*}$ & $-3.15 \pm 0.01^{\mathrm{a}}$ & $-3.56 \pm 0.01^{\mathrm{a}}$ & $-4.18 \pm 0.00^{\mathrm{a}}$ & $-4.37 \pm 0.01^{\mathrm{a}}$ & $-4.62 \pm 0.01^{\mathrm{a}}$ & $-4.78 \pm 0.03^{\mathrm{a}}$ \\
$\mathrm{b}^{*}$ & $28.99 \pm 0.01^{\mathrm{a}}$ & $33.33 \pm 0.03^{\mathrm{b}}$ & $46.78 \pm 0.02^{\mathrm{c}}$ & $53.71 \pm 0.01^{\mathrm{d}}$ & $56.37 \pm 0.10^{\mathrm{d}}$ & $55.28 \pm 0.09^{\mathrm{d}}$ \\
$\Delta \mathrm{E}$ & - & $4.46 \pm 0.02^{\mathrm{a}}$ & $17.85 \pm 0.01^{\mathrm{b}}$ & $24.81 \pm 0.01^{\mathrm{c}}$ & $27.49 \pm 0.06^{\mathrm{d}}$ & $26.50 \pm 0.05^{\mathrm{d}}$ \\
Color parameters & & & & & & \\
Browning index & $0.15 \pm 0.14^{\mathrm{a}}$ & $0.22 \pm 0.02^{\mathrm{b}}$ & $0.33 \pm 0.01^{\mathrm{c}}$ & $0.48 \pm 0.01^{\mathrm{d}}$ & $0.57 \pm 0.01^{\mathrm{e}}$ & $0.72 \pm 0.01^{\mathrm{f}}$ \\
Total carotenoids $(\mathrm{mg} / \mathrm{kg})$ & $0.82 \pm 0.03^{\mathrm{a}}$ & $0.90 \pm 0.02^{\mathrm{a}}$ & $1.10 \pm 0.01^{\mathrm{b}}$ & $1.38 \pm 0.04^{\mathrm{c}}$ & $1.99 \pm 0.05^{\mathrm{d}}$ & $2.41 \pm 0.04^{\mathrm{e}}$ \\
Total chlorophylls $(\mathrm{mg} / \mathrm{kg})$ & $0.24 \pm 0.08^{\mathrm{a}}$ & $0.28 \pm 0.07^{\mathrm{a}}$ & $0.39 \pm 0.08^{\mathrm{b}}$ & $0.49 \pm 0.06^{\mathrm{c}}$ & $0.61 \pm 0.03^{\mathrm{d}}$ & $0.70 \pm 0.03^{\mathrm{d}}$ \\
\hline
\end{tabular}

$\dagger L^{*}$ lightness of the sample $(0=$ black, $100=$ white $)$; $a^{*}$ indicates redness by positive or greenness by negative; $b *$ indicates yellowness by positive or blueness by negative; $\Delta \mathrm{E}$, color difference.

*Browning index, specific UV extinction at the wavelength of $442 \mathrm{~nm}$.

Mean values denoted by the same letter in the rows do not constitute statistically significant differences at $p<0.05$.

(Table 2). After $100 \mathrm{~min}$ of seed roasting, the amount of both groups of pigment increased by nearly 3 -fold, when compared to the control oil sample.

\subsection{Color development of rapeseed oil pressed from de-hulled seeds as a function of roasting time}

The control oil sample was characterized by a light yellow color, without the typical green hue, due to the removal of hulls, which impart a greenish color to cold-pressed rapeseed oil. The browning index of untreated oil was 0.15 . With the increase in roasting time from 20 to $100 \mathrm{~min}$, an increase in the browning index (from 0.22 to 0.72 ) took place (Table 2). The lightness $\left(\mathrm{L}^{*}\right)$ of the oils and the red-green color coordinate $\left(\mathrm{a}^{*}\right)$ gradually decreased with the increase in seed roasting time; however, only minor changes with respect to these color coordinates were seen. On the other hand, the rate of change in the yellow-blue color coordinate $\left(b^{*}\right)$ increased significantly with roasting time. The $b^{*}$ value for the control oil sample was 28.99 , after 80 and $100 \mathrm{~min}$ of seed roasting and its value was nearly 2 -fold higher than in the control oil sample. A significant negative correlation between the amount of carotenoids and the $\mathrm{L}^{*}$ and $\mathrm{a}^{*}$ color parameters was found $(\mathrm{r}=-0.948$ and -0.929 , respectively), whereas a strong positive correlation was noted for the $\mathrm{b}^{*}$ parameter $(r=0.918)$. A visible oil color change from light yellow to light brown with the increase in roasting time was also assessed in terms of changes in the calculated color difference $(\Delta \mathrm{E})$ value (Table 2$)$. Similar to the changes in the browning index values, it was found that the greatest color difference in the analyzed oil samples was observed in oils pressed from seeds roasted for 80 and $100 \mathrm{~min}$ $(\Delta \mathrm{E}=27.49$ and 26.50 , respectively)

\subsection{Effect of de-hulled rapeseed roasting on the DPPH radical scavenging activity of rapeseed oil}

Table 3 shows the DPPH radical scavenging activities (RSC), as expressed by the TEAC values of the analyzed oils for both hydrophilic (HF) and lipophilic fractions (LF), as well as for whole oil (TF). The respective RSC values of LF, HF and TF of the control oil sample were $0.88,0.32$, and $1.34 \mathrm{mmol} / \mathrm{L}$. As a result of prolonged roasting time, a significant increase in the radical scavenging activity of HF was recorded; while only slight changes in TEAC values were noted for LF. As the roasting time increased to $100 \mathrm{~min}$, the TEAC values evaluated for HF, LF and TF were as follows: 2.30, 1.55, $3.98 \mathrm{mmol} / \mathrm{L}$, respectively. A statistical analysis showed a significant effect of increased content of the hydrophilic-like compounds and TEAC values of the HF of the oils studied. A significant correlation between antioxidant capacity and total phenolic contents was found $(r>0.9)$. The RSC value of $\mathrm{HF}$ was found to correlate best with the content of canolol $(r=0.959)$. The statistical analysis also showed a significant effect of the increased content of lipophilic-like compounds and TEAC values of LF in the oils. The Pearson correlation coefficient was $r=0.981, r=0.952, r=0.624$, for phytosterols, carotenoids, and tocopherols, respectively.

\subsection{Effect of de-hulled rapeseed roasting on the oxidative stability of rapeseed oil}

De-hulled rapeseed roasting prior to pressing resulted in the formation of hydroperoxides, a primary lipid oxidation product. The lowest hydroperoxide level, measured by peroxide value (PV), was found in the control oil sample $\left(0.79\right.$ meq $\left.\mathrm{O}_{2} / \mathrm{kg}\right)$, whereas the PV of the 100-min roasted sample reached a maximum value of $2.89 \mathrm{meq} \mathrm{O}_{2} / \mathrm{kg}$, 
TABLE 3. DPPH radical scavenging activity (mmol TEAC/l) and oxidative stability parameters of rapeseed oil samples produced from de-hulled roasted seeds

\begin{tabular}{|c|c|c|c|c|c|c|}
\hline Roasting time (min) & $\mathbf{0}$ & 20 & 40 & 60 & 80 & 100 \\
\hline \multicolumn{7}{|c|}{ DPPH Radical scavenging activity (mmol TEAC/I)* } \\
\hline $\mathrm{HF}$ & $0.32 \pm 0.05^{\mathrm{a}}$ & $0.46 \pm 0.01^{\mathrm{b}}$ & $1.25 \pm 0.04^{\mathrm{c}}$ & $1.56 \pm 0.03^{\mathrm{d}}$ & $1.98 \pm 0.06^{\mathrm{e}}$ & $2.30 \pm 0.05^{\mathrm{f}}$ \\
\hline LF & $0.88 \pm 0.02^{\mathrm{a}}$ & $0.92 \pm 0.03^{\mathrm{a}}$ & $1.04 \pm 0.05^{\mathrm{b}}$ & $1.34 \pm 0.05^{\mathrm{c}}$ & $1.51 \pm 0.04^{\mathrm{d}}$ & $1.55 \pm 0.05^{\mathrm{d}}$ \\
\hline $\mathrm{TF}$ & $1.34 \pm 0.03^{\mathrm{a}}$ & $1.42 \pm 0.02^{\mathrm{a}}$ & $2.41 \pm 0.05^{\mathrm{b}}$ & $2.99 \pm 0.04^{\mathrm{c}}$ & $3.56 \pm 0.05^{\mathrm{d}}$ & $3.98 \pm 0.05^{\mathrm{e}}$ \\
\hline \multicolumn{7}{|c|}{ Oxidative stability parameters $\dagger$} \\
\hline $\mathrm{PV}\left(\mathrm{mEq} \mathrm{O}_{2} / \mathrm{kg}\right)$ & $0.79 \pm 0.06^{\mathrm{a}}$ & $0.99 \pm 0.15^{\mathrm{b}}$ & $1.34 \pm 0.05^{\mathrm{c}}$ & $1.62 \pm 0.07^{\mathrm{d}}$ & $2.45 \pm 0.09^{\mathrm{e}}$ & $2.89 \pm 0.13^{\mathrm{f}}$ \\
\hline$p$-AnV & $0.24 \pm 0.08^{\mathrm{a}}$ & $0.28 \pm 0.07^{\mathrm{a}}$ & $0.39 \pm 0.08^{b}$ & $0.49 \pm 0.06^{\mathrm{b}}$ & $0.61 \pm 0.03^{\mathrm{c}}$ & $0.70 \pm 0.03^{\mathrm{c}}$ \\
\hline$K_{232}$ & $0.82 \pm 0.03^{\mathrm{a}}$ & $0.90 \pm 0.02^{\mathrm{a}}$ & $1.10 \pm 0.01^{\mathrm{b}}$ & $1.38 \pm 0.04^{\mathrm{c}}$ & $1.99 \pm 0.05^{\mathrm{d}}$ & $2.41 \pm 0.04^{\mathrm{d}}$ \\
\hline$K_{268}$ & $0.09 \pm 0.02^{\mathrm{a}}$ & $0.15 \pm 0.09^{\mathrm{a}}$ & $0.21 \pm 0.04^{\mathrm{b}}$ & $0.28 \pm 0.09^{\mathrm{b}}$ & $0.39 \pm 0.06^{\mathrm{c}}$ & $0.44 \pm 0.02^{\mathrm{c}}$ \\
\hline IP (h) & $4.27 \pm 0.03^{\mathrm{a}}$ & $4.28 \pm 0.15^{\mathrm{a}}$ & $4.62 \pm 0.12^{\mathrm{a}}$ & $5.09 \pm 3.53^{b}$ & $6.47 \pm 0.07^{\mathrm{c}}$ & $6.85 \pm 0.07^{\mathrm{c}}$ \\
\hline
\end{tabular}

*Antioxidant activity of: hydrophilic fraction (HF); lipophilic fraction (LF) and whole oil (TF).

$\dagger$ PV, peroxide value; $K$, specific UV extinction at the indicated wavelength (nm); IP, induction period (h) determined by Rancimat test at $120^{\circ} \mathrm{C}$.

Mean values denoted by the same letter in rows do not constitute statistically significant differences at $p<0.05$.

which was 3.6-fold higher than that of the control oil sample (Table 3). Although seed roasting prior to pressing altered the content of primary oxidation products considerably $(p<0.05)$, none of the oil samples reached the upper limit for PV of 15 meq $\mathrm{O}_{2} / \mathrm{kg}$. Along with prolonged seed roasting time, a simultaneous increase in the content of primary oxidation products was observed, resulting from the decomposition of hydroperoxides under elevated temperatures. The roasting of dehulled rapeseeds significantly increased the level of aldehydes, assessed in terms of changes in the p-AnV (from 0.24 to 0.70 ). Roasting time in the range of 20-100 min resulted in the formation of conjugated dienes $\left(K_{232}\right)$ and trienes $\left(K_{268}\right)$, whose level increased from 0.82 to 2.41 and from 0.09 to 0.44 , respectively (Table 3 ). The results of the oil stability evaluation based on the Rancimat test are given in Table 3. It was found that roasting time exerts a statistically significant effect $(p<0.05)$ on the induction period (IP) of the oils studied. The control oil sample was characterized by the lowest induction period (IP) of $4.27 \mathrm{~h}$, and with increasing roasting time, a gradual increase in IP occurred. The IP was 4.28, 4.62, 5.09, 6.47, and $6.85 \mathrm{~h}$ of the oil pressed from seeds roasted for 20, 40, 60, 80, and $100 \mathrm{~min}$, respectively.

\section{DISCUSSION}

The main constituents of rapeseed oil unsaponifiables are tocopherols and phytosterols (Przybylski, 2011). According to Codex Alimentarius crude rapeseed oil contains $4500-11300 \mathrm{mg} / \mathrm{kg}$ of phytosterols and $430-2680 \mathrm{mg} / \mathrm{kg}$ of tocopherols. Wijesundera et al. (2008), who studied the effect of rapeseed roasting at $165^{\circ} \mathrm{C}$ for $5 \mathrm{~min}$ found that a thermal pre-treatment of seeds prior to pressing resulted in a modest increase in $\gamma-\mathrm{T}(10 \%)$ with a practically unchanged content of $\alpha-T$. Similar results were presented by Siger et al. (2015), who reported that whole rapeseed roasting at 140,160 and $180{ }^{\circ} \mathrm{C}$ for 5,10 and $15 \mathrm{~min}$ increased $\gamma$-T (up to $37 \%$ in seeds roasted for $15 \mathrm{~min}$ at $180{ }^{\circ} \mathrm{C}$, when compare to the control oil), but no significant difference in the amount of $\alpha-T$ was found. On the contrary, Shrestha and De Melnauer (2014) found the rapeseed roasting pre-treatment at $180{ }^{\circ} \mathrm{C}(10-90 \mathrm{~min})$ to increase the content of $\alpha-T$ and decrease the $\gamma$-T concentration by up to $6-7 \%$, when compared to the control oil. In our study, rapeseed roasting pre-treatment resulted in an increase of up to $21 \%$ in $\gamma-\mathrm{T}$, while the decrease in the concentration of $\alpha-\mathrm{T}$ amounted to $16 \%$. As Wijesundera et al. (2008) suggested, slight alterations in tocopherol levels in oils produced from roasted seeds may result from tocopherol co-elution in HPLC with other compounds formed during seed roasting. According to Matthäus (2013) it is possible that canolol acts as an antioxidant protecting tocopherols from degradation during the seeds' thermal pre-treatment. Similar to tocopherol content, the amount of plastochromanol-8 increased gradually due to longer seed heating time (Table 1). This observation concurs with the results obtained by Shrestha and De Meulenaer (2014), who found rapeseed roasting at $165^{\circ} \mathrm{C}$ for $10 \mathrm{~min}$ to increase PC-8 significantly, whereas Siger et al. (2015) noted a decrease in the PC-8 content during rapeseed roasting at 140 and $160{ }^{\circ} \mathrm{C}$ for 5,10 and $15 \mathrm{~min}$.

Ghazani et al. (2014) found the effect of rapeseed oil production method on the level of phytosterols to be significant. The highest level of total phytosterols was found in solvent-extracted 
oil $(940.8 \mathrm{mg} / 100 \mathrm{~g})$, followed by oil produced by hot-pressing $(836.5 \mathrm{mg} / 100)$, and cold-pressing $(835.8-774.1 \mathrm{mg} / 100 \mathrm{~g})$, while the lowest content of phytosterols was found in fully refined rapeseed oil $(613.5 \mathrm{mg} / 100 \mathrm{~g})$. By the application of roasting pretreatment for $100 \mathrm{~min}$ we were able to increase the amount of total phytosterols by up to $6 \%$, in comparison to the control oil sample. Whole rapeseed roasting for $1 \mathrm{~h}$ at $80,100,120,140{ }^{\circ} \mathrm{C}$ was reported to cause a gradual increase in the total phytosterol content in the oil (Rękas et al., 2015). In contrast, Siger et al. (2015) found the roasting of rapeseed at 140, 160 and $180{ }^{\circ} \mathrm{C}(5-15 \mathrm{~min})$, in general, to decrease the total content of phytosterols. In turn, Yang et al. (2013), who treated whole rapeseed with microwaves $(0-8 \mathrm{~min}, 800 \mathrm{~W})$ noted that phytosterol contents in the rapeseed oil increased with increasing microwave time and with decreasing initial moisture content of the rapeseeds.

The level of total phenolic compounds detected in rapeseed oil depends heavily on the production procedure, rapeseed variety and ripening degree, in addition to the method of extraction and type of solvent used (Kozłowska et al., 1990). Yang et al. (2014) showed that the use of Folin-Ciocalteu reagent may result in an overestimation of total phenolic content by comparing the total phenolic content in rapeseed oil measured by the Folin-Ciocalteau method and calculated from UPLC data $(28.53 \mathrm{mg} / 100$ $\mathrm{g}$ vs. $19.94 \mathrm{mg} / 100 \mathrm{~g}$ ), as it may react with amino acids (alanine, cysteine, glycine, tryptophan), sugars (fructose, glucose, sucrose) or easily oxidized substances. In comparison with other oilseeds, rapeseed contains comparatively high amounts of phenolic compounds, of which esterified phenolic acids are present in the largest quantities (Naczk et al., 1998). However, due to their hydrophilic nature, only a small proportion of phenolic acid is transferred to the oil (Yang et al., 2014). Unlike other phenolics, canolol, due to its molecular structure, shows better solubility in oil. As a result, canolol constitutes a dominant phenolic compound found in rapeseed oil (Kraljić et al., 2013; Shrestha and De Melnauer, 2014; Yang et al., 2014; Siger et al., 2015). The canolol concentration in rapeseed oil pressed from roasted seeds greatly depends on the applied heating temperature, duration of heating and moisture content of the seeds. However, the available data in the literature considering the effect of rapeseed thermal pre-treatment on the formation of canolol is inconsistent. According to Spielmeyer et al. (2009) canolol is thermally unstable and undergoes degradation at temperatures above $165{ }^{\circ} \mathrm{C}$, while Matthäus (2013) stated that substantial amounts of canolol precede rapeseed roasting at temperatures above $180^{\circ} \mathrm{C}$. Mayengbam et al. (2013) found that ground rapeseed roasting at $200{ }^{\circ} \mathrm{C}$ for $15 \mathrm{~min}$ increased the content of canolol up to 2000-fold, when compare to the control oil $(0.003$ to $6.671 \mathrm{mg} / \mathrm{g})$. Yang et al. (2014) found that after a microwave exposure time of rapeseeds for $7 \mathrm{~min}(800 \mathrm{~W})$ the amount of canolol in the seeds increased by more than 6 times (increase from 14.07 to $89.89 \mathrm{mg} / 100 \mathrm{~g}$ ), while in the oil canolol content was 9-fold higher than that of unheated rapeseed oil (increase from 17.06 to $162.71 \mathrm{mg} / 100 \mathrm{~g})$.

Carotenoid pigments present in crude oil possess antioxidant activity, especially in the light, in contrast to chlorophyll pigments, which act as pro-oxidants when exposed to light. Ghazani et al. (2014) found a 10-fold higher content of chlorophyll pigments in solvent-extracted rapeseed oil than in that of cold-pressed oil. The content of chlorophylls in rapeseed depends primarily on the degree of ripeness. Moreover, as shown by Kraljić et al. (2013), rapeseed variety is also an important factor. The de-hulling of rapeseeds leads to the removal of major parts of the fiber and a group of hull pigments such as chlorophylls (Niewiadomski, 1990). The amount of chlorophyll in the control oil obtained from de-hulled rapeseeds was $0.24 \mathrm{mg} / \mathrm{kg}$, which is nearly 2 to 3 times lower in comparison with the chlorophyll pigment content in coldpressed oil pressed from whole rapeseeds (Kraljić et al., 2013; Ghazani et al., 2014). Following 100 min of seed roasting the concentration of chlorophylls in the oil increased to $0.70 \mathrm{mg} / \mathrm{kg}$, which is consistent with the results presented by Prior et al. (1991), who reported that heating rapeseeds at $80-100{ }^{\circ} \mathrm{C}$ for $30 \mathrm{~min}$ significantly affected chlorophyll content $(6.5 \mathrm{mg} / \mathrm{kg}$ for cold-pressed oil, up to 47.3 and $67.8 \mathrm{mg} / \mathrm{kg}$ for roasting at 80 and $100{ }^{\circ} \mathrm{C}$, respectively). The favorable effect of rapeseed pre-treatment on the extractability of carotenoid pigments was reported by Kraljić et al. (2013) and Rękas et al. (2015). In contrast, carotenoids were found thermally-unstable during the roasting $\left(150{ }^{\circ} \mathrm{C}\right.$ for $\left.10,20,30,40,60 \mathrm{~min}\right)$ of pine nuts (Cai et al., 2013). A similar correlation between roasting pre-treatment $\left(160{ }^{\circ} \mathrm{C}\right)$ and the amount of lutein content in mustard oil was presented by Vaidya and Choe (2010).

Color is an important criterion for cold-pressed oils. Hull removal allowed us to produce rapeseed oil characterized by a light-yellow hue; however, roasting of the seeds resulted in a color change to light brown. The darkening of oil with an increase in roasting time may result from the formation of Maillard type browning reaction products, the release of phospholipids (Shrestha and De Meulenaer, 2014) and furfural derivatives (Durmaz and Gökmen, 2010).

Higher extractability of compounds possessing antioxidant activity released (tocochromanols, carotenoids) or generated (canolol) during the roasting process resulted in increased radical scavenging activity and oxidative stability of the resulting oil. Additionally, other factors, such as the formation of lipophilic Maillard type browning reaction products 
may be responsible for such effect. Uquiche et al. (2008) and Yang et al. (2013) suggested that the greater oxidative stability of oils obtained from roasted seeds may also result from inactivation of pro-oxidative enzymes, such as lipase, peroxidase, and lipoxygenase. Namiki (1995) and Shrestha and De Meulenaer (2014) pointed out that enhanced oxidative stability of roasted sesame oil and rapeseed oil results from the synergistic effect among different components with antioxidant activity. Moreover, phospholipids, released as a result of thermally-induced lipid bilayer degradation, may affect oil oxidation through the sequestering of trace pro-oxidant metals, such as iron (Choe and Min, 2006).

\section{CONCLUSIONS}

The results obtained in this study show that a de-hulled rapeseed roasting pre-treatment for different times, ranging from 20 to $100 \mathrm{~min}$, significantly affected the extractability of bioactive compounds. The applied roasting conditions did not alter the content of tocopherols or polar phenolic compounds; whereas a gradual increase in phytosterols, and carotenoids was noted, and a remarkable increase in the canolol concentration was found. A synergistic effect among the different antioxidant active compounds resulted in the increase in radical scavenging activity and oxidative stability; however, with the increase in roasting time, the formation of hydroperoxides and their degradation products was noticeable. Although de-hulled rapeseed roasting prior to pressing enabled the production of an oil with added value in nutritional terms, browning processes as well as changes in the sensory assessment are of great importance in order to produce high quality rapeseed oil.

Abbreviations: HF: hydrophilic fraction; IP: induction period; LF: lipophilic fraction; $\boldsymbol{p}$-AnV: $p$-anisidine value; PC-8: plastochromanol-8; PV: peroxide value; RSC, radical scavenging activity; $\alpha$-T: alpha tocopherol; $\beta$-T: beta-tocopherol; $\gamma$-T: gamma-tocopherol; $\delta$-T: delta-tocopherol.

\section{Conflict of interest statement}

The authors have declared no conflict of interest.

\section{REFERENCES}

Aachary AA, Thiyam-Holländer U. 2013. An update on characterization and bioactivities of sinapic acid derivatives, in: Thiyam-Holländer U, Eskin NAM and Matthäus B (Eds.) Canola and Rapeseed: Production, Processing, Food Quality, and Nutrition. Taylor \& Francis, CRC Press, Boca Raton, USA, 21-38.

Anders A. 2003. Rapeseed coat removal using disks equipped with cylindrical blades. Technical Sci. 6, 65-72.

AOCS Official Method. 1997. Determination of chlorophyll related pigments in oil (AOCS Method Cc 13d-55).

AOCS Official Method. 1997. Determination of the composition of the sterol fraction of animal and vegetable oils and fats by TLC and capillary GLC (AOCS Method Ch 6-91).
Azadmard-Damirchi S, Habibi-Nodeh F, Hesari J, Nemati M, Achachlouei BF. 2010. Effect of pretreatment with microwaves on oxidative stability and nutraceuticals content of oil from rapeseed. Food Chem. 121, 1211-1215. http:// dx.doi.org/10.1016/j.foodchem.2010.02.006

Brühl L, Matthäus B. 2008. Sensory assessment of virgin rapeseed oils. Eur. J. Lipid Sci. Tech. 110, 608-610. http:// dx.doi.org/10.1002/ejlt.200700293

BSI. 1977. Methods of analysis of fats and fatty oils. Other methods. Determination of carotene in vegetable oils. British Standards Institution, London (BSI 684-2.20).

Cai L, Cao A, Aisikaer G, Ying T. 2013. Influence of kernel roasting on bioactive components and oxidative stability of pine nut oil. Eur. J. Lipid Sci. Technol. 115, 556-563. http://dx.doi.org/10.1002/ejlt.201200337

Carré P, Citeau M, Robin G, Estorges M. 2016. Hull content and chemical composition of whole seeds, hulls and germs in cultivars of rapeseed (Brassica napus). OCL 23, A302. http://dx.doi.org/10.1051/ocl/2016013

Durmaz G, Gökmen V. 2010. Determination of 5-hydroxymethyl-2-furfural and 2-furfural in oils as indicators of heat pre-treatment. Food Chem. 123, 912-916. http:// dx.doi.org/10.1016/J.Foodchem.2010.05.001

FAOSTAT. 2015. http://faostat3.fao.org/download/T/TP/E

Ghazani SM, García-Llatas G, Marangoni AG. 2014. Micronutrient content of cold-pressed, hot-pressed, solvent extracted and RBD canola oil: Implications for nutrition and quality. Eur. J. Lipid Sci. Technol. 116, 380-387. http://dx.doi.org/10.1002/ejlt.201300288

Guderjan M, Elez-Martínez P, Knorr D. 2007. Application of pulsed electric fields at oil yield and content of functional food ingredients at the production of rapeseed oil. Innov. Food Sci. Emerg. 8, 55-62. http://dx.doi.org/10.1016/j.ifset.2006.07.001

$\mathrm{Hu}$ Z-Y, Hua W, Zhang L, Deng L-B, Liu G-H, Hao W-J. 2013. Seed structure characteristics to form ultrahigh oil content in rapeseed. PLoS One 8, e62099. http://dx.doi. org/10.1371/journal.pone.0062099

ISO 1996. Animal and vegetable fats and oils. Determination of peroxide value. International Organization for Standardization, Geneva (ISO 3960).

ISO 2008. Animal and vegetable fats and oils. Determination of anisidine value. International Organization for Standardization, Geneva (ISO 6885).

ISO 2011. Animal and vegetable fats and oils. Determination of ultraviolet absorbance expressed as specific UV extinction. International Organization for Standardization, Geneva (ISO 3656)

Koski A, Psomiadou E, Tsimidou M, Hopia A, Kefalas P, Wähälä K. 2002. Oxidative stability and minor constituents of virgin olive oil and cold-pressed rapeseed oil. Eur. Food Res. Technol. 214, 294-298. http://dx.doi.org./doi:10.1007/ s00217-001-0479-5

Kozłowska H, Naczk M, Shahidi F, Zadernowski R. 1990. Phenolic acids and tannins in rapeseed and canola, in Shahidi F. (Ed) Canola and Rapeseed. Production, Chemistry, Nutrition and Processing Technology, NY, Van Nostrand Reinhold, 193-210.

Kraljić K, Škevin D, Pospišil M, Obranović M, Nederal S, Bosolt T. 2013. Quality of Rapeseed Oil Produced by Conditioning Seeds at Modest Temperatures. J. Am. Oil Chem. Soc. 90, 589-599. http://dx.doi.org/10.1007/s11746-012-2195-7

Mayengbam S, Khattab R, Thiyam-Holländer U. 2013. Effect of conventional and microwave toasting on sinapic acid derivatives and canolol content of canola. Cur. Nutr. Food Sci. 9, 321-327. http://dx.doi.org/10.2174/15734013090413 1122094946

Naczk M, Amarowicz R, Sullivan A, Shahidi F. 1998. Current research developments on polyphenolics of rapeseed/ canola: A Review. Food Chem. 62, 489-502. http://dx.doi. org/10.1016/S0308-8146(97)00198-2

Namiki M. 1995. The chemistry and physiological functions of sesame. Food Rev. Int. 11, 281-329. http://dx.doi. org/10.1080/87559129509541043

Niewiadomski H. 1990. Primary processing, in Niewiadomski H. (Ed.) Rapeseed Chemistry and Technology. Warszawa, PWN-Polish Scientific Publishers, 161-183. 
Prior EM, Vadke VS, Sosulski FW. 1991. Effect of heat treatments on canola press oils. I. Non-triglyceride components. J. Am. Oil Chem. Soc. 68, 401-406. http://dx.doi.org/10.1007/ BF02663756

Przybylski R. 2011. Canola/Rapeseed Oil, in Gunstone FD (Ed.) Vegetable Oils in Food Technology: Composition, Properties and Uses. Blackwell Publishing Ltd., Hoboken, 107-136.

Rękas A, Wroniak M, Rusinek R. 2015. Influence of roasting pretreatment on high-oleic rapeseed oil quality evaluated by analytical and sensory approaches. Int. J. Food Sci. Tech. 50, 2208-2214. http://dx.doi.org/10.1111/ijfs.12884

Shrestha K, De Meulenaer B. 2014. Effect of seed roasting on canolol, tocopherol, and phospholipid contents, Maillard type reactions, and oxidative stability of mustard and rapeseed oils. J. Agric. Food Chem. 62, 5412-5419. http:// dx.doi.org/10.1021/jf500549t

Siger A, Kachlicki P, Czubiński J, Polcyn D, Dwiecki K, NogalaKałucka M. 2014. Isolation and purification of plastochromanol-8 for HPLC quantitative determinations. Eur J. Lipid Sci. Tech. 116, 413-422. http://dx.doi.org/10.1002/ ejlt.201300297

Siger A, Kaczmarek A, Rudzińska M. 2015. Antioxidant activity and phytochemicals content in cold-pressed rapeseed oil obtained from the roasting seeds. Eur. J. Lipid Sci. Tech. 117, 1225-1237. http://dx.doi.org/10.1002/ ejlt.201400378

Spielmeyer A, Wagner A, Jahreis G. 2009. Influence of thermal treatment of rapeseed on the canolol content. Food Chem. 112, 944-948. http://dx.doi.org/10.1016/j. foodchem.2008.07.011

Thiyam-Holländer U, Eskin NAM, Matthäus B. 2013. Canola and Rapeseed Production, Processing, Food Quality, and Nutrition. Boca Raton, Taylor \& Francis.

Tuberoso CIG, Kowalczyk A, Sarritzu E, Cabras P. 2007. Determination of antioxidant compounds and antioxidant activity in commercial oilseeds for food use. Food Chem. 103, 1494-1501. http://dx.doi.org/10.1016/j.foodchem.2006.08.014

Uquiche E, Jeréz M, Ortíz J. 2008. Effect of pretreatment with microwaves on mechanical extraction yield and quality of vegetable oil from Chilean hazelnuts (Gevina avellana Mol). Innov. Food Sci. Emerg. 9, 495-500. http://dx.doi. org/10.1016/j.ifset.2008.05.004

Wijesundera C, Ceccato C, Fagan P, Shen Z. 2008. Seed roasting improves the oxidative stability of canola (B. napus) and mustard (B. juncea) seed oils. Eur. J. Lipid Sci. Tech. 110, 360-367. http://dx.doi.org/10.1002/ejlt.200700214

Yang M, Huang F, Liu Ch, Zheng Ch, Zhou Q, Wang H. 2013. Influence of Microwave Treatment of Rapeseed on Minor Components Content and Oxidative Stability of Oil. Food. Bioprocess. Tech. 6, 3206-3216. http://dx.doi.org/10.1007/ s11947-012-0987-2

Yang M, Liu Ch, Huang F, Zheng Ch, Zhou Q. 2011. Effect of Dehulling Treatment on the Oxidative Stability of ColdPressed Low Erucic Acid Rapeseed Oil. J. Am. Oil Chem. Soc. 88, 1633-1639. http://dx.doi.org/10.1007/s11746-011-1822-z

Yang M, Zheng Ch, Zhou Q, Liu Ch, Li W, Huang F. 2014. Influence of Microwaves Treatment of Rapeseed on Phenolic Compounds and Canolol Content. J. Agric. Food Chem. 62, 1956-1963. http://dx.doi.org/10.1021/ jf4054287

Yoshida H, Takagi S, Mitsuhashi S. 1999. Tocopherol distribution and oxidative stability of oils prepared from the hypocotyls of soybeans roasted in microwave oven. J. Am. Oil Chem. Soc. 76, 915-920. http://dx.doi.org/10.1007/ s11746-999-0106-3

Zhou Q, Yang M, Huang F, Zheng C, Deng Q. 2013. Effect of pretreatment with dehulling and microwaving on the flavor characteristics of cold-pressed rapeseed oil by GC-MSPCA and electronic nose discrimination. J. Food Sci. 78, C961-C970. http://dx.doi.org/10.1111/1750-3841.12161 